\title{
Ideological and Lexical Deviance of Western Media in Reflecting Socio-political Events of Pakistan
}

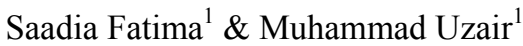 \\ ${ }^{1}$ National University of Modern Languages, Islamabad, Pakistan \\ Correspondence: Saadia Fatima, National University of Modern Languages, Islamabad, Pakistan. E-mail: \\ saadia.fatima@hotmail.com; prof.uzair@gmail.com
}

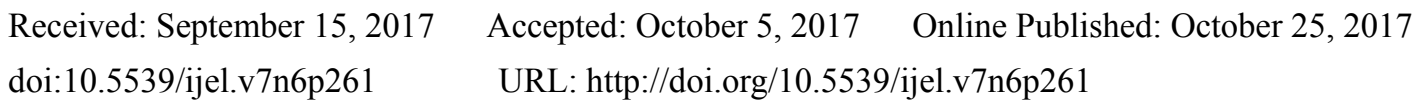

\begin{abstract}
The research in hand has the objectives to analyse how ideologies are expressed through discourse practices in Western media; how a discourse practice and a linguistic strategy in terms of lexical choices are employed in portraying ideologies in media about Pakistan. Grounded on the theoretical framework of Van Dijk's approach of Ideology in critical discourse analysis, the socio-cognitive model was used for analysis which is the most appropriate to study media discourse, the data is analysed qualitatively. The method of the current research is critical discourse analysis. The research revolves around the Pakistani socio-political events in Western media from the perspective of a global issue that is a war on terrorism. The research has objectives to investigate what and how Western media has used lexical choices to depict a certain ideology about Pakistan to the world.
\end{abstract}

Keywords: ideology, critical discourse analysis, lexicon, socio-cognitive

\section{Introduction}

The global political unrest, increased terrorism, rivalry and the controversies in which Pakistan has been involved have led this country to stay on news and media for an extended period of time. The way Pakistan is depicted in Western media is not hidden from the world (McClure, 2009).

The incident of September 11, 2001, has been written in history as the most devastating and the symbolic attack on the US Department of Defense. The loss of around 3000 lives was the worst ever terrorist attack that ever took on the US soil (Friedman, 2002). After the incident of 9/11, in the same morning, the CIA Director George Tenet stated that Osama Bin Laden was the mastermind behind this attack and also mentioned that, "He had the capacity to plan multiple attacks with little or no warning."

Media-promoted phrases and actions like, "Attack on America", "War on America" and "America under Attack", while directly or indirectly pointing out the Islamic countries and transforming the image of America from "America Strikes Back" to "America's New War" even before any official action was taken by the military. In contrast, the Pakistani journalists avoided stereotype characterisation or the use of religious extremist words, statements or activities (Zelizer \& Allan, 2011). Where the Pakistani press completely avoided descriptive characterisation while covering this incident on the news, the British press concluded that all Muslims were the same and each of the Muslims was characterised to be a militant or terrorist. The hatred against the Muslims was clearly seen in the news of British and America (Schlenger et al., 2002).

The world after the incident of September 11, 2001, entered into the drastic phase of fear and terror which was just the starting point of change in the world overall. Extreme uncertainty and fear were seen travelling across the world in all directions; East and West. "War on terrorism" was declared by the United States against any terrorist brand that was considered guilty and responsible for this deadly act (Graham, 2008). The general public did not realise that this war against Afghanistan was planned well before the incident of 9/11 dragging Pakistan in between and forcing them to go against their neighbouring country (Burke, 2008).

This flared up not so new trend called Islamophobia. It is mainly defined to be the discrimination, alienation, violence, harassment that is rooted in the stereotyped and misinformed representation of the religion Islam and its supporters (Kingsbury, 2008). The fact that the hatred towards Muslims around the world is as old as the religion they follow that is Islam, but the term Islamophobia has comparatively been a recent neologism which is primarily used so that the attention could be drawn towards normalized prejudice and Muslims could be a victim 
of unjustified discrimination (Kaplan, 2006). The post-cold war along with the incident of 9/11 has given rise to this phenomenon. It is clearly an anti-Muslim sentiment which the Americans address as "Muslims; the new enemy" (Gottschalk \& Greenberg, 2008). Muslims were discriminated, targeted and differentiated on the basis of extremism and moderation; all these factors increased violence against the Muslims. It is clearly a vicious cycle, and a self-fulfilling prophecy is backlashing the Muslims and making Americans more Islamophobic (Kaplan, 2006).

The fact that the role media has played to promote Islamophobia cannot be ignored. The visual media has to be worthy of consideration due to its open and closed-views related to Muslims and Islam (Sheridan, 2006). What they refer to Islam in their media is the closed-view and considers it to be a "manipulative quasi-religious political entity". The Western media depicts Islam as a violent and hostile religion; it (Western media) prompted the West to promote a cold war against Muslims based on Islamophobia (Silberstein, 2002).

After the terrorist attack of $9 / 11$, there has been serious issues and problems created in the international relations of Pakistan (Scahill, 2009). Incident also resulted in the United States taking the support of other countries to embark on this enterprise that is the campaign against the network of al Qaeda which was accused of carrying out the attack. Pakistan had supported the United States and has proven to be the strongest base in terms of air access, basing and the sea, along with logistics and the intelligence support (Rubin \& Rashid, 2008). As this was the case, Pakistan also contributed into this war by deploying a huge number of troops along the borders of Afghanistan to support Operation Enduring Freedom (OEF).

Media did not leave any chance to create panic amongst the people by creating an image that their next neighbourhood country had attacked them. Media, in fact, assists the terrorist by helping them spread terror and scare the general public on a massive scale (Saeed, 2007). The endless rumours, the hype and the fear that the media created were much more than what was actually happening in real (Corera, 2008).

In an interview given to Asma Sherazi on ARY News in the year 2009 in Pakistan, on a question Hillary Clinton as United States Secretary of State, replied while she totally dusted her shoulders off, of taking any responsibility and said that "it's not our war, it's your war" and further said "I don't know that has much to do with us". (ARY News Official, 2009).

\subsection{Background of the Study}

Language is a socially constructed phenomenon, or in other words, it reflects reality. Language is also a significant means of communication when it comes to the social context (Premack, 2004).

In the world, there are several communities, just like there are countless individuals and each community has their own language in order to develop and express their values, ideas and attitudes (Labov, 2011). The geographical regions are also one of the most important aspects to define the language community and the relationship between the language, and the region reflects their politics, unique identity, and history of the population. The awareness of the nature of language communities definitely provides an insight into the population that helps an individual to be more efficient when it comes to using and understanding a language that the other uses (Ungerer \& Schmid, 2013).

The structure used by individuals and what is employed at the end of a language is engaged primarily in discourse referring to the structures that are combined in real life situations (Pan \& Kosicki, 1993). It is also said that the discourse characteristics will primarily be shaped on the basis of educational and psychological factors. The psychological factors include the likes and dislikes of individuals whereas the educative factors include the opportunities to be literate and enhance the attitude, mainly focusing on the prescriptivism (Hodge \& Kress, 1993). All the roads directly or indirectly lead to discourse, while language is something that focuses on extending the roads leading to discourses (Lippi-Green, 1997).

Ideology and discourse are two practised critical and scholarly concepts applied in the field of social sciences or humanities. It is presupposed that this analysis could either be done with the help of close reading and systemic understanding of languages or through communication (Fowler, 2013). The analysis of the circumstances includes the situations, participants, outcomes and the purpose for which they are associated typically (Harootunian, 1988). As discourse is way beyond just language in use, it could be related to the cultural, political and social formations, reflecting social order and shaping social orders to shape the interactions of individuals within a society (Xiaojin, 2008).

Language, discourse, and ideology in the news are primarily concerned with the description of the features of linguistics that indicate the biased ideologies in the process of representation. The prime goal is clearly seen to be pedagogical that is informative or educational since a reader is instructed how to perceive the values that are 
imposed subliminally by language on the representation of media and news (Van Dijk 2004).

It is quite evident from the study that the international politicians, states officials, writers, newscasters, and bloggers have an entirely different stance from the country Pakistan, leading to a completely different ideology of both the countries. Where the ideology of Pakistan is neutral, and the nation tries to peace out with the world, the ideology of West is highly ideological leading to a wrong impression of the country amongst the world.

In the light of above discussion, the research will proceed with the following research objectives.

\subsection{Research Objectives}

- To investigate how ideologies are expressed, enacted and reproduced by discourse, through semantic choices.

- To highlight semantic choices which are employed in Western media to portray socio-political events in Pakistan.

- To investigate how some linguistic choices are used to reflect a certain ideology in the media.

\subsection{Research Questions}

1) How does the reflection of socio-political events of Pakistan in international media reveal its ideology? Moreover, how does the news ideology carry the element of bias in representing Pakistan?

2) What is the role of different semantic/lexical choices employed to depict that ideology?

3) How does ideological meaning depict ideology? How do lexical choices in the news portray a certain ideology?

\section{Literature Review}

The word "social" is an adjective that is derived from society. It means, relating to society. The word political means: concerning of or to the state, the government, policy-making and public administration (Oxford, 2012). A socio-political event refers to an event that involves social and political factors. There are several studies reviewed following that involves discourse analysis from the perspective of ideology, hegemony, and power in the social and political scenario.

Critical discourse analysis refers to the uncovering of several implicit theories which are mentioned in texts. It exposes several underlying ideological prejudices by exercising the power of text. There are several approaches to critical discourse analysis (CDA); these approaches differ in terms of the theoretical foundation. Norman Fairclough believes that a language and a choice of words shape the social identities of people along with the knowledge systems and beliefs (Fairclough, 1992). The other theory is presented by Van Dijk and according to his point of view, the mental, as well as the personal doctrines about the ethnic events, influence the way things are interpreted (Van Dijk, 1993). The author believes that there are two ways of talking and presenting information. These two ways are positive self-representation and negative other-representation (Van Dijk, 2006). This lead to belief and ideology and ideologies are basically social representation through which a group is defined as a social identity (Manicas, 1991). Under the label of cognition, there would be an analysis of beliefs and ideas of nature and the association with knowledge and opinions and the socially formulated status (Wodak, 2006). When the transformation of ideology to discourse is concerned and studied, it should be focused that the influence of ideology should primarily be on the structure of discourse. In the socio-linguistic study, there is no ideological marking of grammatical structures (Scollon, 1995).

There are a number of significant research studies on CDA, Rhetoric, and Systemic Functional Linguistics (SFL) aiming to investigate political discourses in other veins and genres as follows. Ali \& Kazemian (2015) have probed a speech by Liaquat Ali Khan titled "Pakistan and the Modern World" in light of Van Dijk's socio-cognitive model to highlight the important aspects of discourse production and comprehension as well as a reading text "Pakistan Zindabad" to identify problems showing the gap and unawareness on the part of teachers and students regarding the critical discourse of the text in classroom reading context. They are mainly pursued to discover how the language of a politician pursues people in the enactment of power dominance, and the imposition of ideology.

In another study, Zhou \& Kazemian (2015) have analyzed John F. Kennedy's Inaugural Address based on Burkean Identification theory to figure out how the speaker has achieved its rhetorical effect, and have discussed how the politician has used the identification strategies to transcend division, gain identification, induce cooperation, and thus, realize their motives.

In some other veins, Kazemian \& Hashemi $(2014,2017)$ have introduced an integrated approach to analyse 
political or other discourses in light of overarching methodological frameworks of Hallidayan Grammatical Metaphor in SFL, Fairclough's perspective on critical discourse analysis and Rhetoric. They have analyzed $\mathrm{Mr}$ Obama's eight speeches from the point of frequency and functions of nominalisation, rhetorical strategies, passivisation and modality to first manifest the integrated approach practicality and adeptness through analysis; then by virtue of analysis to unveil how language is manipulated and distorted by orators in order to convey seamlessly intended messages and political creeds to the audience.

Surveying the recent annals of literature, some other considerable studies have also investigated various political, advertisement etc. discourses in light of CDA, SFL and Rhetoric to discern multiple strategies exploited by orators and political pundits and how they make the text/talk persuasive, significant, appealing and obscure, as well as how they convey their intended objectives to the audience (Cap \& Okulska, 2013, Kazemian et al., 2013; Kazemian \& Hashemi, 2014; Noor et al., 2015). Prior studies have tended to concentrate on some other genres and discourses. This study is unique in the sense that it attempts to bridge the gap between previous studies by analysing ideological and lexical deviance of western media in reflecting socio-political events of Pakistan.

\section{Methodology}

The focus of this entire study is in discourse analysis with respect to a certain ideology of a specific social group. The research paradigm by Gephart (2004) is classified into three different philosophical categories which are positivism, subjectivism, and the interpretivism. These three categories are conveniently placed and used in the theories of linguistics, psychology, and sociology. The research in hand lies in interpretive paradigm. Postmodernism along with post-structuralism are two of the factors that research paradigm inherits, within the concept of the critical theory.

From this stems the theory of critical discourse analysis, critical discourse analysis (CDA) is basically a contemporary approach through which languages and discourses are studied in the social institutions. Critical discourse analysis refers to the bases of the critical theory of language which is used in the social practices tied up with the historical context where the social relations exist (Van Dijk, 1999). The questions which are included in this theory are: how is the text used in a language being positioned? With this language positioning, whose interests are served? What are the interests that are being contradicted? Moreover, what is the eventual consequence of this language positioning? All these questions relate to the power relation with discourse, and so it is called critical discourse analysis. When the theoretical framework is studied, it refers to the framework consisting of several concepts which are relevant to the theories of the study. Considering that the media plays a significant role in developing the ideology of society, the researcher for this study has taken the aspect of ideology as a theoretical framework and revolving the entire study around this concept.

The qualitative research design would fit best for this study as it would be effective to identify the behaviour of different groups of people and their experiences (Strauss \& Corbin, 1998). It is said that in the socio-cognitive model which is selected for this study from the ideology approach, there are two divergent ways of analysing the perspective which is the contextual analysis and the textual discourse analysis. Van Dijk who primarily deals with news in the press, knowledge and context, ideology and discursive racism, presented this socio-cognitive model which creates a relationship between the cognitive structure, that is, the one and only way through which the social structures and heterogeneous discourse structures are linked theoretically. Textual analysis is an important strategy to explore the socio-cognitive model in the ideology approach. When talking about the generalised strategy of text discourse, the idea is how to positively present the actions of "Us", with regards to the negative presentation of "Them" and their actions. In the text discourse analysis, the emphasis is primarily on "Us" and "Them" underlined dichotomy, on the level of meaning; form; and action emphasising on the good things of "Us" against "Their" bad things and de-emphasizing on "Their" good things versus "Our" bad things. However, this research is delimited to the analysis on the level of meaning and specifically selecting positive or negative semantic choices or lexicons for "Us" or "Them" (e.g., "terrorist" versus "freedom fighter" and "terrorism" versus "freedom movement").

Official website of BBC (www.bbc.com) is selected out of some options available depending on the fact that it is one of the most popular and reliable sources covering almost all the issues around the world and most importantly, BBC having its bureau office in Pakistan. The reason for selecting the complete news story /article and not just a headlines or heading is because one cannot get a complete ideological understanding underlying a discourse if the text or discourse is analysed in isolation and not within that communicative situation.It might fail to achieve its full purpose otherwise also critical discourse analysis is a holistic tool of analysis, and it cannot take place in isolation.

This study takes into account purposeful sampling as a part of the research methodology. For this particular study, 
there have been the selective pieces of news chosen relevant to the study that is from the channel BBC to evaluate the use of its language reflecting socio-political issues in Pakistan and different terrorist activities happening in the country. As this is the case, the criterion-I sampling which is an essential technique in purposeful sampling shares a variety of characteristics with the random sampling. In this case, the sample is selected based on the experience and their knowledge regarding a particular phenomenon. For delimiting the samples from the year 2009 for this thesis embeds a significant reason. The year 2008-09 was the most significant year and hence carries a huge reason to be selected for analysis in terms of following. One, there were more than 140,000 Pakistani forces were deployed on Pakistan Afghanistan border, which is the maximum number of forces ever deployed since 2001 (Khan, 2012). Second, 89\% of all the operations since 2001, was conducted in the year 2007-09 and mainly in the year 2009 either major or minor operations (Khan, 2012). Third, according to "Pakistan Security Report 2009" by PIPS published in the 2009, 2,586 terrorists, insurgent, and sectarian incidents were informed that killed 3,021 people and injured 7,334 (Wasim, 2010). Fourthly, according to Pakistan Institute of Peace Studies, there were more than 3500 of causalities faced by Pakistan armed forces in the year 2009 which is the largest number of causalities since 2001 (Amir, 2009). Fifth, according to State bank of Pakistan even though foreign reserves increased noticeably from $\$ 10.83$ billion in the year 2007-08 to $\$ 14.75$ billion in October 2009, however, inflation increased $21 \%$ in the year 2008-09 from 10.3\% in the year 2007-08. The sharp increase in foreign reserves is mainly due to the IMF-approved loan of $\$ 11.3$ billion (November 2008), with a total of the foreign loan exceeding as much as $\$ 50$ billion (Khan, 2012). So on the basis of the mentioned reason, the year 2009 entails the significant reasons that should be analyzed, that having contributed so much to this war on terrorism; and having suffered a lot from the war on terrorism, what is the stance of Western media and how does it reflects its ideology either positive or negative about Pakistan. The news story has been segmented into different paras for the conventicle to carry out detailed analysis.

\section{Analysis}

\subsection{Textual Discourse Analysis}

The ideological implicature of hooking on the two countries together is that if one of them is accused of being convicted of something negative, it is also applied to the other as well that is "Them". Talking about Pakistan with Afghanistan is a strategy to bring them parallel in terms of Afghan government (newly elected) failure; it's "undermanned", "undertrained" and not so "equipped" army is implied to bring Pakistan to the same level and creating an ideological "Them". By attaching Afghanistan and Pakistan together the sense of "attachment" has been given to the two by creating a sense of "Them" and also by detaching Pakistan from West and its media that is, "Us". Afghanistan, being the hub of the most of the extremist groups as being discussed in the news, Pakistan, on the other hand, is not launching any such groups and rather being victim itself. It is being discussed in the heading with Afghanistan and also mentioned to face a decisive year, shows an ideological bias by matching and connecting the two states attached to one action. The word "decisive" being used in the heading is used as hyperbole because for Pakistan it is not a decisive year rather Pakistan is either being a victim or being on the forefront to fight for internal as well as global terrorism. So the word "decisive" is a biased model for being used with Pakistan keeping in mind the efforts and struggles to fight against terrorism locally and globally, as the position and stance of Pakistan are being suspected as in the war on terrorism by saying that it will also face a decisive year together with Afghanistan. The news story has been divided into paragraphs for convenience and numbered those sequentially to execute the analysis precisely and closely.Moreover, it is convenient to refer to the specific part of the dataset this way.

Following is the detailed para-wise analysis.

(Para 2)If both nations fail to achieve a modicum of political stability and success against extremism and economic growth, the world will be faced with an expansion of Islamic extremism, doubts about the safety of Pakistan's nuclear weapons and major questions about US prestige and power as it withdraws from Afghanistan.

In the para, words like "Islamic extremism" shows a biased model and ideologically biased choice of an adjective with the word "extremism". Islam is the religion of the majority of the people of Afghanistan and Pakistan is criticised and the lexical choice of the adjective "Islamic" with the word "extremism" questions the religion of the people of Pakistan and Afghanistan. This is one commonality between Afghanistan and Pakistan, and by talking about religion here, it not only combines these two countries on this common ground but also associated the negative meaning that BBC associated with Islam and people related to it, including Pakistan. Also the lexicon "withdraw" in saying that the United States will have to withdraw from Afghanistan if the two states fail in political stability; success against extremism and economic growth rather than choosing the words surrender, quit, yield, defer shows a positive association with the United States hence "Us". 
(Para 3)The challenges for both countries are deeply interlinked and enormous.

The use of lexicon by BBC like "challenges" with "enormous" and "interlinked" with Pakistan in this para depicts a negative ideological association with Pakistan and "Them". The word which depicts a competitive situation in terms of ability and strength makes Pakistan one of "Them" and hence "out-group", and adjectives like "enormous" amplifies and maximises the noun it is being used with. Such lexical choices not only dichotomise "Us vs Them" but also triggers a negative meaning associated with Pakistan.

(Para 4)The primary task is whether both countries can work together with the Western alliance to roll back the Taliban and al-Qaeda threat they face.

The lexical choice of words depicting danger, hazard, and risks like "threats" with Pakistan shows the negativity associated with Pakistan and also the consequences of such words.

(Para 5)That in turn rests on the success of the US and NATO's new strategy in both countries over the next 18 months as President Barack Obama has pledged to stabilise Afghanistan's political and economic institutions and start handing over Afghan security to the Afghan armed forces, starting in July 2011.

The selection of lexicons like "pledge", "handing over", to "stabilize" with Obama, the president of United States depicts some ideological trait of power and powerfulness that is being affiliated with Obama and hence "Us"- the one who is at giving end and grants the things to the less powerful.

(Para 10)The Afghan army is still undermanned, undertrained and has yet to be equipped with heavy weapons and an air force.

The lexical choices like, "undermanned, undertrained" and "yet to be equipped", with Afghan army and air force is a right selection of adjectives to be used. Since Afghanistan is discussed with Pakistan in bold and bigger font in title creates a visual marker of oneness, universality, and binary between Afghanistan and Pakistan, therefore having used such lexical choices shows a negative ideological meaning about Pakistan to highlight using Afghan "umbrella" to conceal all accomplishments and positive traits of Pakistan armed forces.

(Para 11)The Afghan army also suffers from 80\% illiteracy and a lack of recruits from the Pashtun belt, which are essential if the army is to be effective in the Taliban-controlled southern and eastern parts of the country.

The lexical choices like that of "illiteracy" and "lack" of recruits for Afghan army are a negative ideological meaning with Afghan army and Afghanistan. This cannot be ignored in terms of critically analysing this discourse from Pakistan's perspective as throughout this news story, Pakistan is created in binary with Afghanistan and both are ideologically and firmly assumed one of "Them". Hence such ideologically strong lexical items, being used with Afghanistan and not using any lexical items that are positive for Pakistan is a strategic implicature to marginalise the contribution of Pakistan army in the war of terrorism.

(Para 14)Instead, the Taliban will try to expand Taliban bases in the north and West of the country, where they can demoralise the forces of European Nato countries that are facing growing opposition at home about their deployment.

BBC has selected the word "demoralise" with European NATO forces when they come face to face with Taliban. Instead of using the word to fight, to come in the state of war, or wrestle, rather BBC has the careful lexical selection where it depicts that Taliban CAN try to "demoralise" European NATO forces but not to have in position to fight, or war or coming face to face with them. This shows an ideological showcasing of powerfulness, being strong in numbers and weapons of West and European NATO forces. The word "demoralise" is too mild and moderate a word which means dispirit and discourage but not by any chance coming face to face with an equal position as to fight. It is not appropriate to be used with European forces when they are facing Taliban which is a worldwide threat for terror according to them. Here BBC has focused more on adoring West and European forces rather than felt a need to highlight danger and risk of Taliban coming face to face with them. This can be compared to the lexical choice in para 9 for the verb "wrangling" when it was a total exaggerated and even harsh choice to be used with the political matter of whether or not to have parliamentary elections again. Since politics is a different domain and military is a different one, so BBC tries not to display West or European NATO forces on the vulnerable side or open to risk, to be blamed for not coming up with the standards as BBC itself has been undermining Afghan army and air force in the news already.

(Para 17)Without Pakistan eliminating these sanctuaries or forcing the Afghan Taliban leadership into talks with Kabul, US success in Afghanistan is unlikely.

In this para the negative lexical choices like "Without" being used with Pakistan in "Without Pakistan eliminating..." semantically carries a negative ideology being associated with Pakistan. Whereas it could have 
been assimilated as "With Pakistan... success is likely" by making it one of "Us", but BBC chose a semantic option carrying a negative meaning and at the same time created an "out-group" mood by selecting the word "Without" and that too at the beginning of a sentence. At the same time, the positive word "success" associated with the United States depicts a positive, strong and powerful "Us", whereas it could have been "the US cannot be successful or US failure is likely". Hence just to avoid the words like "failure" and "cannot be successful" being used with the United States, BBC chose the better and positive word "success" with the United States hence "Us", shows an ideological positivity associated with the United States.

(Para 18) Pakistan itselffaces a triple crisis

- $\quad$ acute political instability - President Asif Ali Zardari may soon be forced to resign, which could trigger long-term political unrest

- $\quad$ an ever-worsening economic crisis that is creating vast armies of jobless youth who are being attracted to the message of extremism

- $\quad$ the army's success rate in dealing with its own indigenous Taliban problem.

In these lines, lexical choices by BBC reveal its ideology. BBC has chosen intense negative words. The entirely overall and consistent selection of these words (verbs and noun) sound and depict a negativity in itself like, "forced", "resign", "trigger", and "message of extremism", clearly shows a negative ideology of BBC for Pakistan and at the same time dissociating Pakistan from "Us".

BBC shows an ideological negativity associated with Pakistan by using sever negative adjectives and magnifying the negativity like used in, "triple crisis", "political instability", "political unrest", "ever-worsening economic crisis", "jobless youth", and "own indigenous Taliban problem". The negative semantic choice is obvious. Either for the verbs and nouns or adjectives, BBC is depicting negative ideology altogether in this para. So the direct and obvious lexical choice is considered a deliberate depiction of negative ideology associated with Pakistan at the same time making "Them" distant and distinct from "Us".

(Para 19)The key to any improvement rests on the army and the political forces coming to a mutual understanding and working relationship with each other and providing support to Western efforts in Afghanistan.

In these lines of $\mathrm{BBC}$ news article, $\mathrm{BBC}$ here seems to positively ideologically portray West by using positive words saturated with positivity in itself like "improvement" "mutual understanding", "support" and "Western efforts". BBC shows an alliance with West, United States by making a powerful "Us" which is demonstrated by its deliberate lexical choices of all the words which not only depict a positivity but optimism as well. However, the words "support", "efforts" with Western in concluding phrase exhibit an explicit positive ideology associated with West.

(Para 20)However, for the moment that appears unlikely while the army is hedging its bets with the Afghan Taliban, as it is fearful about a potential power vacuum in Afghanistan once the Americans start to leave in 2011.

The lexical choices like, "fearful" "hedging its bets" shows a weak and vulnerable picture of Pakistan and also a state which is not interested in peace in the region overall, but is playing more diplomatic for merely its own interest. However, these two lexical choices totally differ with facts because on one hand, Pakistan army is very clear about its stance as conducted several operations of which $89 \%$ have been carried out in the year 2008-09; faced maximum fatalities in 2009 and still being chosen to characterize "fearful", is BBC's negative ideology associated with it. Also the selection of words "potential power" suggests a positive meaning and ideology associated with Americans as to magnify and glorify its presence in Afghanistan by depicting it a real superpower, whose absence may lead an insecurity and fear to Pakistan hence depicted weaken here.

(Para 22)Pakistan's fight against its own Taliban is going well but that is insufficient as long as the army does not move militarily or politically against the Afghan Taliban or other Punjab-based extremist groups now allied with the Taliban.

If the lexical choice is considered, it is self-evident that $\mathrm{BBC}$ very explicitly seems to choose the adjectives like "insufficient" as for Pakistan's fight or in other words its contribution in the past and now ongoing fight for global terrorism. Talking about "own Taliban" and using the adjective "own" with a threatening figure like "Taliban" is to associate a sense of indigenousness or "homegrown" product. Whereas Pakistan never owns these Taliban since they are imposed or came illegally to the land mostly. Keeping this fact and still choosing these semantically negative and magnified choices with Pakistan, is just ideologically negative impact shows for Pakistan.

(Para 23)Pakistani calculations also involve India-and the failure of both nations to resume the dialogue halted 
after the 2008 attacks in Mumbai (Bombay).

Just like the heading "impasse", the content discussed under the heading seems to have to carry more of the ideologically negative words associated with Pakistan hence "Them". The lexical choices like "failure" with Pakistan as a nation and direct the readers to think towards an overtly negative direction for Pakistan depict a negative ideology BBC possess. Also, the word like "halted" with dialogue shows a selection of negative choices hence a negative ideology being associated with Pakistan.

(Para 24)India fears that extremist Punjabi groups could launch another Mumbai-style attack and are demanding that Pakistan break up all indigenous extremist groups that fought in Indian-administered Kashmir in the 1990s.

The lexical choice like that of "fears" for using it with India who is the biggest nearby enemy of Pakistan and blaming Pakistan for launching attacks like that of Mumbai attacks 2008. Having used this word "fears" with Pakistan's enemy who always accuse Pakistan of either flaring up extremist groups in Kashmir or launch an attack in Mumbai, this type of lexical choices make Pakistan look more of troublesome and terrifying neighbouring country and hence an ideologically negative "Them". Also, BBC chose to use the word "Indian-administrated Kashmir" and not Indian occupied Kashmir, depicts that BBC has used an Indian stance in dealing with Kashmir dispute and not that of Pakistan's. Hence BBC has created an "out-group" for Pakistan and hence treated as one of "Them".

(Para 26)The Obama administration has so far failed to persuade India and Pakistan to resume a dialogue or settle their differences, and if that remains the case in the new year, Pakistan is more than likely to continue defying US pressure to help with Afghanistan.

In this para, BBC chose word "defying" for Pakistan. According to Oxford Dictionary the word "defy" means refuse to obey. Here using this word for Pakistan against United States' pressure, makes Pakistan not on equal terms with the United States but this word pictures more of a "master-slave" relation, where Pakistan is a slave which is bound to obey its master or is bound to work under its master's pressure. Such lexical choices portray Pakistan, not an ally with the United States in the war on terrorism but just an "out-group" entity and one of "Them" which is an ideological opponent.

(Para 27)There is growing anti-Americanism in Pakistan despite Washington's pledge of an annual \$1.5bn aid package for the next five years.

The lexical choices of adjectives like "growing" and nouns like "anti-Americanism" which also implies an ideology and then using it with Pakistan proposes, Pakistan having an opposite ideology which is not a pro-American ideology clearly states BBC's lexical choices are highly ideological and adverse for Pakistan. The use of adjective "growing" is hence magnifying and even intensifying the "anti-Americanism" scenario which is prevailing according to BBC. Such lexical choices are ideological and make Pakistan one of "Them".

(Para 28)With the present lack of security in Pakistan - and the volatile mood towards the US and India that is partly being fueled by the military -it is difficult to see how US aid can be effectively spent or how other economic investments can take place.

The words like "lack of security", "volatile mood" "fueled by the military", show some adverse lexical choices by BBC for Pakistan. Adjectives like "lack" with security; "volatile" with mood and using verbs like "fueled" with the military; are visibly negative and adverse choice of words which shows a negative ideology BBC possess for Pakistan.

(Para 30)The recent arrests in the US and Europe of suspects linked to the Afghanistan-Pakistan region indicate that the world could face a wider extremist threat if it fails to effectively stabilise Afghanistan and help Pakistan towards a quick economic and political recovery.

The lexical choices of BBC like "extremist threat" because of Pakistan is the choice of negative words that shows $\mathrm{BBC}$ takes Pakistan as an ideological opponent and BBC's portrayal, itself by using such lexical choices is an ideologically negative picture that it shows.

The news story is analysed, probing into each segment separately. It is, however, significant to analyse this news on the whole. The overall mapping of the news story does not suggest a positive picture portrayed by BBC about Pakistan. However, the detailed analysis says the same. The very title "Afghanistan and Pakistan face decisive year" of the news comprises a biased model. This title suggests a oneness and universality of the two countries. Each segment is analysed at the contextual as well as the textual level to seek how Western media has reflected the socio-political events of Pakistan. The overall analysis is essential to knit the small segments at large. 
The opening of the news story comprises of the rhetorically hyperbolic expressions "holding their breath" which gives a dramatic opening to the news and gives an ideologically not very positive meaning to people of South Asia, and Pakistan in specific. The first five paras create a subtle specification of meaning to create oneness and universality and a binary between Pakistan and Afghanistan. BBC shows concern about the United States' "prestige and power" in withdrawing from Afghanistan without stabilising it. At the same time, it says that challenges that Pakistan and Afghanistan face are "deeply interlinked" and also "enormous". While BBC is linking the two countries, their challenges, on the other hand, it makes it a point of concern for the United States to save its "prestige and power" in front of the world. While opponent, "Them" is drawn to be "interlinked" in facing Taliban and Al Qaeda threats, the other, "Us" is concerned about its "prestige and power" in front of the world.

The Afghanistan is not only treated as Pakistan's geographical neighbour, but ideologically it is also considered Pakistan's neighbour in terms of destabilising Pakistan's image and reflecting a certain ideology. The achievements of Pakistan army in the war on terrorism are not hidden from the world and West, and the United States may secretly admire. However, the ideological "to and fro" and shift shows that this representation is subjective and is the result of biased models.

\section{Conclusion}

The current study sought to find out the ideology of Western media and how they reflected or presented the ideology about Pakistan by using biased models, and lexical choices to present the bad picture of "Them". This chapter aims to establish an effective conclusion of the entire research and evaluate how far the research aims and objectives of the study were achieved. The aim was to reveal how the selected news of BBC had reflected the ideology about Pakistan to the rest of the world. The study aimed to explore how Western media reflect Pakistani-sociopolitical event, from the perspective of war on terrorism conforming to a specific ideology.

The conclusion of the entire study is followed by the research findings and the recommendations. This chapter aims to represent the Western ideology and evaluate how media played a significant role in influencing the mindsets of the audience who trusts them blindly.

The study sought to find how some lexicons can reflect the ideology of media. There is no lexicon that is ideologically biased. It was the certain use of the lexical items that make it ideologically biased. BBC intentionally chose such lexical items to present a certain image of Pakistan to the world. It manifests the aspects which have a certain ideology. Considering Pakistan an ideological opponent, BBC had depicted that notion categorically which was evident in the news discourse covering Pakistan. The Western media created a biased contextual model along with biased lexical choices and presented a scripted view of Pakistan which was very much negative .

The media inaccuracy, the distortion in news and the omission of reality and biases in news of the West had been obvious and cannot be ignored since the use of the words and the representation have influenced the overall society economically, militarily, culturally as well as politically as there have been many issues caused resulting from concentrated views and manipulations.

It shall not be ignored that the West, the United States and Western media had raised a propaganda of war on terrorism, involving Afghanistan and dragging Pakistan and forcing it to ally with them and go against their neighbouring country so that the United States can invade Afghanistan.

\subsection{Findings of the Research}

In the light of the in-depth analysis of Western media, i.e., BBC and above conclusion, the researcher has analysed and summed up the findings of how the Western media reflect socio-political events of Pakistan. Following are the findings of the research.

1) BBC carried a specific negative ideology in its news discourse which does not conform to Pakistan's interests and failed to create a positive image of Pakistan to the world. BBC had solely conformed to Western ideology by conforming western interests particularly. As Pakistan had been dichotomised ideologically with West, on the other hand, BBC had "in grouped" itself with West.

2) The media either ideologically combined Pakistan with a threatening figure like Afghan Taliban in general and Afghanistan in specific, to ideologically associate all the shortcomings related to Afghanistan with Pakistan, in terms of Afghanistan's "undermined".

3) BBC used vigilant lexical choices very shrewdly and deliberately for displaying "Our" sovereignty, supremacy, pacifism, qualities ; showing "Us" as mediator and peacekeeper role; and the choices which showed 
treacherous "Them", On the other hand it depicted menace for Pakistan, which magnifies the problems faced by Pakistan and image building words like showing Pakistan is safeguarding terrorists and provide "sanctuaries", had been used.

4) On one hand BBC used direct and image building words to create Pakistan's negative image, words which are ideologically biased, on the other hand $\mathrm{BBC}$ also used lexical choices which did not give a direct impression of negativity about "Us" and avoided to use the negative formation of sentence which included the word "not" even where it has to. Instead, it used the mildest word for doing the purpose of negation where it mentioned West or United States refusing or not agreeing to some global matter of universal importance.

5) There had been such image building intensified and exaggerated lexicons chosen which make Pakistan seem a global threat and not just confined to West. Such lexical choices magnified the negative ideology of Western media about Pakistan and also shaped up the same ideology in receiver's mind.

\subsection{Recommendations}

The media plays a significant role to create the image of any, person gender, social group, and even a country and could have a grave impact on building any perception about a country to the world. In the past years, it has been observed that Western media has been playing an important role in presenting the eastern society; especially Pakistan. This research in hand also concludes how Western media has presented its ideology about Pakistan its socio-political events and issues and emphasising its weaknesses and vaguely marginalising its strengths. The manipulation and propaganda created by the Western media have been quite obvious has been concluded without any doubt. The media whether it is Western or Eastern or belong to any part the world, be it print electronic or cyber media, carries lots of responsibility to convey the reality and truth. The main aim of the media should be, to highlight the actual realities no matter what social group it belongs to. It is recommended to consider the code of ethical conducts while producing and giving the news. At the same time, media houses need to pay particular attention to be neutral and not to play with feelings of masses as to handle the sensitive issues like religion so ruthlessly. BBC has played with emotions of Pakistanis and Muslims all over the world by referring to "expansion of Islamic" extremism. Extremism is a state of mind like fanaticism this too is a mental disorder, and by associating it with Islam puts a big question and at the same time hampers the feelings of Muslims. Such ruthless remarks can result in resentment, hatred and can ignite insurgency amongst the target masses for the media house, policy makers or at large the country it belongs to. It is recommended for media houses not use language for the defamatory purposes.

The media has the duty and discretion to serve the public honestly and without any discrimination of colour, creed, gender, culture, social group, ethnicity or country. International media should pay special attention, not to single out a specific class or country just for their foreign policy goals. Media needs to be beyond all the global politics. At the same time, there is a strong need, for media houses to understand their positive role and formulate their channel policies without any discrimination of any kind. There should be some internationally established standards in setting parameters that should be defined in black and white and categorically, for the rights of individual as well as larger domain institutes, not to be hampered or deteriorate linguistically not even covertly. For this individual as well as institutions have to be linguistically so well equipped to know how they can raise a question against such violations. Besides that, there is also a need for every individual to understand how media shapes up their knowledge without even letting the individual know. People intentionally or unintentionally are oblivious how media contour their knowledge in ideologically embedded discourse. Linguistics awareness should not just be confined to academic specialisation; rather individual should get aware of linguistic exploitation for their personal and social interests too.

\section{Acknowledgments}

I would like to thank my instructors throughout my coursework for the valuable guidance in the realm of research and pouring in the best of the knowledge. I specifically thank my supervisor Dr Muhammad Uzair for his excellent support and ultimate help in helping me write this article with his valuable guidance, perfect enlightenment with best of his knowledge.

\section{References}

Ali, S., \& Kazemian, B. (2015). Critical Discourse Analysis of a Reading Text "Pakistan and the Modern World": A Speech by Liaquat Ali Khan. Communication and Linguistics Studies, 1(3), 35-41.

Ali, S., Kazemian, B., \& Bughio, F. A. (2015). An investigation of the reading text "Pakistan Zindabad" (Long Live Pakistan): Critical discourse analysis perspective. Education and Linguistics Research, 1(2), 42-51. https://doi.org/10.5296/elr.v1i2.8160 
Amir. M. (2009). Mapping the Madrassa Mindset: Political Attitude of Pakistani Madaris. Conflict and Peace Studies, 2(1), 31-35.

ARY News Official. (2009). Hillary in conversation with women of Pakistan. Retrieved from https://www.youtube.com/watch?v=m3iMTpVj5e8

Burke, J. (2008). What do the Mumbai attacks mean globally? Daily Times, Friday, November 28.

Cap, P., \& Okulska, U. (Eds.). (2013). Analyzing genres in political communication: theory and practice (Vol. 50). Amsterdam: John Benjamins Publishing. https://doi.org/10.1075/dapsac.50

Corera, G. (2008). Mumbai attacks show tactic changed. Daily Times Friday, November 28th.

Defy. (2014), In OxfordDictionaries.com. Retrieved from https:/en.oxforddictionaries.com/definition/defy

Fairclough, N. (1992). Discourse and social change. London: Polity Press.

Fowler, R. (2013). Language in the News: Discourse and Ideology in the Press. London, New York: Routledge.

Friedman, J. (2002). From nine-eleven to seven-eleven: The poverty of interpretation. Social Analysis: The International Journal of Social and Cultural Practice, 46(1), 104-109.

Gephart, R. P. (2004). Qualitative research and the Academy of Management Journal. Academy of Management Journal, 47(4), 454-462. https://doi.org/10.5465/AMJ.2004.14438580

Gottschalk, P., \& Greenberg, G. (2008). Islamophobia: making Muslims the enemy. USA: Rowman \& Littlefield.

Graham, S. (Ed.). (2008). Cities, war, and terrorism: towards an urban geopolitics. New York: John Wiley \& Sons.

Harootunian, H. D. (1988). Things seen and unseen: Discourse and ideology in Tokugawa nativism. Chicago: University of Chicago Press.

Hodge, R. I. V., \& Kress, G. R. (1993). Language as ideology. London, New York: Routledge.

Kaplan, J. (2006). Islamophobia in America?: September 11 and Islamophobic Hate Crime 1. Terrorism and Political Violence, 18(1), 1-33. https://doi.org/10.1080/09546550500383209

Kazemian, B., \& Hashemi, S. (2014). Nominalizations in scientific and political genres: A systemic functional linguistics perspective. International Journal of Humanities and Social Sciences, 3(2), 211-228.

Kazemian, B., \& Hashemi, S. (2014). Critical discourse analysis of Barack Obama's 2012 speeches: Views from systemic functional linguistics and rhetoric. Theory and Practice inLanguage Studies (TPLS), 4(6), 1178-1187. https://doi.org/10.4304/tpls.4.6.1178-1187

Kazemian, B., \& Hashemi, S. (2017). "A Radical Shift to a Profound and Rigorous Investigation in Political Discourse": An Integrated Approach. International Journal of English Linguistics, 7(3), 115-128. https://doi.org/10.5539/ijel.v7n3p115

Kazemian, B., Behnam, B., \& Ghafoori, N. (2013). Ideational grammatical metaphor in scientific texts: a Hallidayan perspective. International Journal of Linguistics, 4(4), 146-168. https://doi.org/10.5296/ijl.v5i4.4192

Khan, Z. A. (2012). Military operations in FATA and PATA: Implications for Pakistan. Journal of Strategic Studies, 31(4), 32.

Kingsbury, A. (2008). "Five Lessons from the deadly Mumbai Terrorist Attacks as suspicions focus on Pakistani group, new conclusions arise about effectiveness of low-tech plots". US News and World Report

Labov, W. (2011). Principles of linguistic change, cognitive and cultural factors (Vol. 3). New York: John Wiley \& Sons.

Lippi-Green, R. (1997). English with an accent: Language, ideology, and discrimination in the United States. London: Psychology Press.

Manicas, P. T. (1991). History and Philosophy of Social Science.

McClure, K. R. (2009). Madrasas and Pakistan's education agenda: Western media misrepresentation and policy recommendations. International Journal of Educational Development, 29(4), 334-341. https://doi.org/10.1016/j.ijedudev.2009.01.003

Meibauer, J. (2006). Implicature. In K. Brown (Ed.), Encyclopedia of Language and Linguistics (2nd ed., pp. 568-581). New York: Elsevier. https://doi.org/10.1016/B0-08-044854-2/00307-2 
Noor, M., Ali, M., Muhabat, F. \& Kazemian, B. (2015). Systemic Functional Linguistics Mood Analysis of the Last Address of the Holy Prophet (PBUH). International Journal of Language and Linguistics. Special Issue: Critical Discourse Analysis, Rhetoric, and Grammatical Metaphor in Political and Advertisement Discourses, 4(1-1), 1-9. https://doi.org/10.2139/ssrn.2604000

Pan, Z., \& Kosicki, G. M. (1993). Framing analysis: An approach to news discourse. Political Communication, 10(1), 55-75. https://doi.org/10.1080/10584609.1993.9962963

Premack, D. (2004). Is language the key to human intelligence?. Science, 303(5656), 318-320. https://doi.org/10.1126/science.1093993

Rubin, B. R., \& Rashid, A. (2008). From Great Game to Grand Bargain-Ending Chaos in Afghanistan and Pakistan. Foreign Affairs., 87, 30.

Saeed, A. (2007). Media, racism and Islamophobia: The representation of Islam and Muslims in the media. Sociology Compass, 1(2), 443-462. https://doi.org/10.1111/j.1751-9020.2007.00039.x

Scahill, J. (2009). The secret US war in Pakistan. The Nation, 23.

Schlenger, W. E., Caddell, J. M., Ebert, L., Jordan, B. K., Rourke, K. M., Wilson, D., ... \& Kulka, R. A. (2002). "Psychological reactions to terrorist attacks: findings from the National Study of Americans' Reactions to September 11". Jama, 288(5), 581-588. https://doi.org/10.1001/jama.288.5.581

Scollon, R. (1995). Plagiarism and ideology: Identhttps://doi.org/10.1001/jama.288.5.581ity in intercultural discourse. Language in Society, 24(01), 1-28. https://doi.org/10.1017/S0047404500018388

Sheridan, L. P. (2006). Islamophobia pre-and post-September 11th, 2001. Journal of Interpersonal Violence, 21(3), 317-336. https://doi.org/10.1177/0886260505282885

Silberstein, S. (2002). Language, Polities and 9/11 War of words. London, New York: Routledge publishers. https://doi.org/10.4324/9780203341421

Social. (2014), In OxfordDictionaries.com. Retrieved from https://en.oxforddictionaries.com/definition/social

Strauss, A., \& Corbin, J. (1998). Basics of qualitative research: Techniques and procedures for developing grounded theory. Thousand Oaks, California: Sage Publications, Inc.

Ungerer, F., \& Schmid, H. J. (2013). An introduction to cognitive linguistics. London, New York: Routledge.

Van Dijk, T. (1993). Principles of critical discourse analysis. Discourse and Society, 4, 249-283. https://doi.org/10.1177/0957926593004002006

Van Dijk, T. A. (1999). Critical discourse analysis and conversation analysis. Discourse \& Society, 10(4), 459-460. https://doi.org/10.1177/0957926599010004001

Van Dijk, T. A. (2006). Discourse, context and cognition. Discourse Studies, 8(1), 159-177. https://doi.org/10.1177/1461445606059565

Wasim. A. (2010). Over 12,800 militants caught in 2009. Dawn.

Wodak, R. (2006). Mediation between discourse and society: assessing cognitive approaches in CDA. Discourse Studies, 8(1), 179-190. https://doi.org/10.1177/1461445606059566

Xiaojin, L. (2008). News Discourse and Ideology. Science \& Technology Information, 2, 134.

Zelizer, B., \& Allan, S. (Eds.). (2011). Journalism after September 11. London: Taylor \& Francis.

Zhou, Q. \& Kazemian, B. (2015). A Rhetorical Identification Analysis of English Political Public Speaking: John F. Kennedy's Inaugural Address. International Journal of Language and Linguistics. Special Issue: Critical Discourse Analysis, Rhetoric, and Grammatical Metaphor in Political and Advertisement Discourses, 4(1-1), 10-16. 


\section{Appendix}

Afghanistan and Pakistan face decisive year

People in the South Asia region will be holding their breath in the new year.

If both nations fail to achieve a modicum of political stability and success against extremism and economic growth, the world will be faced with an expansion of Islamic extremism, doubts about the safety of Pakistan's nuclear weapons and major questions about US prestige and power as it withdraws from Afghanistan.

The challenges for both countries are deeply interlinked and enormous.

The primary task is whether both countries can work together with the $\mathbf{6 6}$ Without Pakistan eliminating Western alliance to roll back the Taliban and al-Qaeda threat they face.

That in turn rests on the success of the US and Nato's new strategy in both countries over the next 18 months as President Barack Obama has pledged to stabilise Afghanistan's political and economic institutions and start handing over Afghan security to the Afghan armed forces, starting in July 2011.

\section{Karzai undermined}

For that to happen much will depend on whether the West is able to find effective government partners in both Islamabad and Kabul.

So far the prospects are not all that hopeful.

President Hamid Karzai has emerged as the victor after intensely controversial elections that undermined his domestic and international credibility, while the Afghan army is still far from being able to take over major security responsibilities.

There will be renewed political wrangling as the West and the Afghans have to decide whether to hold parliamentary elections in the new year.

The Afghan army is still undermanned, undertrained and has yet to be equipped with heavy weapons and an air force.

The Afghan army also suffers from $80 \%$ illiteracy and a lack of recruits from the Pashtun belt, which are essential if the army is to be effective in the Taliban-controlled southern and eastern parts of the country.

In the midst of what will certainly be a hot and possibly decisive summer of fighting in 2010 between Western forces and the Taliban, the other primary tasks of providing jobs and economic development, while building sustainable capacity within the Afghan government to serve the Afghan people, will be even more important and difficult to achieve.

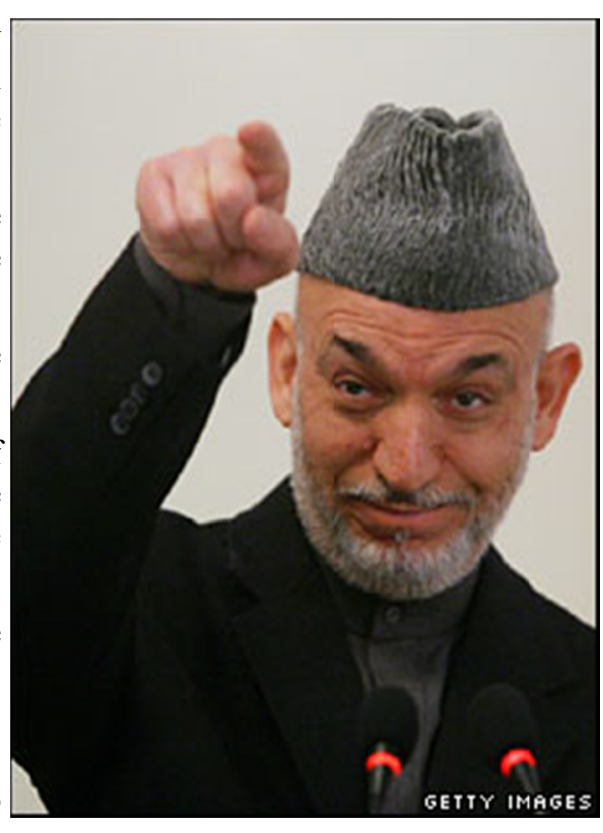

Mr Karzai won a deeply flawed election

The Taliban strategic plan for the summer is likely to be to avoid excessive fighting in the south and east which is being reinforced with 30,000 new American soldiers.

Instead, the Taliban will try to expand Taliban bases in the north and west of the country, where they can demoralise the forces of European Nato countries that are facing growing opposition at home about their deployment.

The militants will also stretch the incoming US troops - forcing them to douse Taliban fires across the country while they try to create greater insecurity in Central Asia.

\section{Pakistan crisis}

At the same time the Pakistan military, which now effectively controls policy towards India and Afghanistan, shows no signs of giving up on the sanctuaries that the Afghan Taliban have acquired in Pakistan. 
Without Pakistan eliminating these sanctuaries or forcing the Afghan Taliban leadership into talks with Kabul, US success in Afghanistan is unlikely.

\section{Pakistan itself faces a triple crisis}

- $\quad$ acute political instability_President Asif Ali Zardari may soon be forced to resign, which could trigger long-term political unrest

- $\quad$ an ever-worsening economic crisis that is creating vast armies of jobless youth who are being attracted to the message of extremism

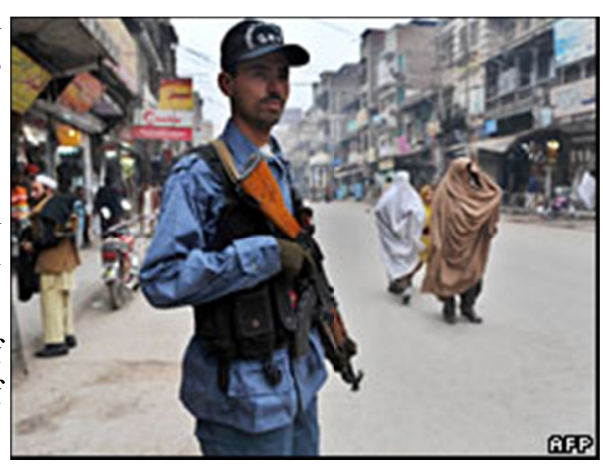

- The army's success rate in dealing with its own indigenous Taliban problem.

Pakistan has been wracked by violence

The key to any improvement rests on the army and the political forces coming to a mutual understanding and working relationship with each other and providing support to Western efforts in Afghanistan.

However, for the moment that appears unlikely while the army is hedging its bets with the Afghan Taliban, as it is fearful about a potential power vacuum in Afghanistan once the Americans start to leave in 2011.

Other neighbouring countries - India, Iran, Russia and the Central Asian republics - may start thinking along the same lines and prepare their own Afghan proxies to oppose the Afghan Taliban, which could result in a return to a brutal civil war similar to that of the 1990s.

Pakistan's fight against its own Taliban is going well but that is insufficient as long as the army does not move militarily or politically against the Afghan Taliban or other Punjab-based extremist groups now allied with the Taliban.

\section{Impasse}

Pakistani calculations also involve India — and the failure of both nations to resume the dialogue halted after the 2008 attacks in Mumbai (Bombay).

India fears that extremist Punjabi groups could launch another Mumbai-style attack and are demanding that Pakistan break up all indigenous extremist groups that fought in Indian-administered Kashmir in the 1990s.

Islamabad is refusing to do so until Delhi resumes talks with it.

The Obama administration has so far failed to persuade India and Pakistan to resume a dialogue or settle their differences and if that remains the case in the new year, Pakistan is more than likely to continue defying US pressure to help with Afghanistan.

There is growing anti-Americanism in Pakistan despite Washington's pledge of an annual \$1.5bn aid package for the next five years.

With the present lack of security in Pakistan - and the volatile mood towards the US and India that is partly being fuelled by the military-it is difficult to see how US aid can be effectively spent or how other economic investments can take place.

At present there is an enormous flight of local capital from both Afghanistan and Pakistan that has increased since the Obama plan was announced.

The recent arrests in the US and Europe of suspects linked to the Afghanistan-Pakistan region indicate that the world could face a wider extremist threat if it fails to effectively stabilise Afghanistan and help Pakistan towards a quick economic and political recovery.

\section{Copyrights}

Copyright for this article is retained by the author(s), with first publication rights granted to the journal.

This is an open-access article distributed under the terms and conditions of the Creative Commons Attribution license (http://creativecommons.org/licenses/by/4.0/). 